\title{
Application of Non Thermal Clarification in Fruit Juice processing - A Review
}

\author{
Harsh P. Sharma ${ }^{1 *}$, Sugandha Sharma ${ }^{2}$, Vaishali ${ }^{3}$ and K. Prasad ${ }^{2}$ \\ ${ }^{1}$ College of Food Processing Technology and Bio-energy, AAU, Anand (Gujarat) India \\ ${ }^{2}$ Department of Food Engineering and Technology, SLIET, Longowal,(Punjab) India \\ ${ }^{3}$ Department of Food Technology,G.J. University of Science and Technology, Hisar (Haryana) India \\ *Email: harshsharma1983@yahoo.co.in
}

\begin{abstract}
Juice and juice products represent a very important segment of the total processed fruit industry. Juice clarification is very important process of the juice production industry as it enhances the acceptability of the product. In clarification process semistable emulsion of colloidal plant carbohydrates that support the insoluble cloud material of a freshly pressed juice is broken such that the viscosity is dropped and the opacity of the cloudy juice is changed to an open splotchy look. For clear juices, complete depectinization by addition of enzymes, fine filtration, or high speed centrifugation will be required to achieve visual clarity. Now a days a number of methods are used for clarification of juice i.e. enzymatic clarification, ultrafiltration, centrifugation, earth filtration and cross flow membrane filtration. Enzymatic treatment for juice extraction is most commonly used now a days. Enzymes are an integral component of modern fruit juice manufacturing and are highly suitable for optimizing processes. Their main purposes are: increase extraction of juice from raw material, increase processing efficiency (pressing, solid settling or removal), and generate a final product that is clear and visually attractive. Nonenzymatic clarification involves breaking the emulsion by other means, the most common of which is heat. Other techniques include addition of gelatin, casein, and tannic acid-protein combinations. For juice clarification, ultrafiltration and microfiltration are now commonly used, representing membranes with pore sizes from 10,000 MWCO to $0.6 \mu \mathrm{m}$. Membrane filtration processes include reverse osmosis, nanofiltration, ultrafiltration, and microfiltration. Advantages of membrane filtration over traditional clarification methods include reduced processing time, increased juice yield, elimination of filter aid and filter presses, better product quality, and reduced enzyme usage. We can conclude from the technical literature that use of the enzymes i.e. Cellulases, pectinases, combination of these enzymes and some non enzyme process can give better quality in terms of clarity of the fruit juice.
\end{abstract}

Keywords: Enzymatic clarification, juice extraction, pectinase, clarity, membrane, ultrafiltration

Fruits and vegetables are important sources of essential dietary nutrients such as vitamins, minerals and fiber. Since the moisture content of fresh fruits and vegetables is more than $80 \%$, they are classified as highly perishable commodities. The world fruit production is about 609,213,509 metric ton in 2010 (FAO STAT, 2010-11). In India, out of the total production of fruits and vegetables, nearly 76 percent is consumed in fresh form, while wastage and losses account for 20-22 percent. Only 4 percent of fruit production are being processed (Indian Horticulture Database, 2013). The production of fruit and vegetable juices is important both from the human health and commercial standpoints. The availability of nutritious components from fruits and vegetables to a wide range of consumers is thus facilitated throughout the year by the marketing of their juices. The production of fruit and vegetable juices requires methods for extraction, clarification and stabilization (Bhat, 2000).Clarification is a process by which the semistable emulsion of colloidal plant carbohydrates thatsupport the insoluble cloud material of a freshly pressed juice is "broken" such that the viscosityis dropped and the opacity of the cloudy juice is changed to an open splotchy look. This can beaccomplished in one of two general ways: enzymatically and non-enzymatically (Kilara and Van Buren, 1989).

Nonenzymatic clarification involves breaking the emulsion by other means, the most common of which is heat. Other techniques include addition of gelatin, casein, and tannic acid-protein combinations (Kilara and Van Buren, 1989). Additionally, the uses of honey and combined honey-pectinase treatments have 
been found to be effective clarification agents. It is believed that the proteinaceous component of honey is responsible for a synergistic effect when honey and pectinase are used in combination (McLellan et al., 1985).

Fruit contains pectin and other polysaccharides so it may lead to fouling during filtration through membrane. Enzymatic treatment leads to degradation of pectin. Enzymatically clarified juice resulted in viscosity reduction and cluster formation, which facilitates separation through centrifugation or filtration. As a result, the juice presents higher clarity, as well as more concentrated flavor and colour (Abdullah et al., 2007).

During the early 1930s, when fruit industries began to produce juice, the yields were low, and many difficulties were encountered in filtering the juice to an acceptable clarity (Uhlig, 1998). Subsequently, research on industrially suitable pectinases, cellulases and hemicellulases from food-grade micro-organisms (Aspergillus niger and Trichoderma sp.), together with increased knowledge on fruit components, helped to overcome these difficulties (Grassin and Fauquembergue, 1996a).Enzymatic treatment for juice extraction and clarification is most commonly used now a days. Enzymatic hydrolysis of the cell walls increases the extraction yield, reducing sugars, soluble dry matter content and galacturonic acid content and titrable acidity of the products (Joshi et al., 1991). The resultant pulp has a lower viscosity and the quantity of waste pomace is reduced (Dorreich, 1996). Enzymatic degradation of the biomaterial depends upon the type of enzyme, incubation time, incubation temperature, enzyme concentration, agitation, $\mathrm{pH}$ and use of different enzyme combinations (Baumann, 1981).

Currently, pectinases, cellulases and hemicellulases collectively called macerating enzymes are used for improvement in pressing, extraction and clarification of fruit and vegetable juices (Galante et al., 1998b). In addition, $\alpha$-amylase and amyloglucosidase, active at acidic $\mathrm{pH}$, were used to process starch containing fruits, especially apples harvested during the early stages in order to prevent haze formation (Grassin and Fauquembergue, 1996a; Uhlig, 1998).

\section{Enzymatic clarification of juices}

Fruit juices are naturally cloudy, yet in different degrees, especially due to presence of polysaccharides (pectin, cellulose, hemicelluloses, lignin and starch), proteins, tannins and metals (Vaillant et al., 2001). As the juice clear appearance is a determinant factor for consumers, the fruit juice industry has been investing in methods that optimize this feature (Tribess and Tadini, 2006). The high concentration of pectin leads to colloid formation, which constitutes one of the main problems during the processing of clear fruit juices. However, although the suspended pulp particles can be removed through filtration, the presence of pectin may make this method difficult (Sulaiman et al., 1998). The depectinisation of fruit juices through the use of pectinases has been presented as an efficient alternative to reduce turbidity, in many studies (Kashyap et al., 2001; Landbo et al., 2007). Pectinases degrade pectin hence resulting in viscosity reduction and cluster formation, which facilitates separation through centrifugation or filtration. As a result, the juice presents higher clarity, as well as more concentrated flavour and colour (Abdullah et al., 2007; Kaur et al., 2004). Pectinase enzymes used in grape juice macerate increased the juice clarity and filterability by $100 \%$ according to Brown and Ough (1981). For clarified fruit juices, a juice that has an unstable cloud or whose turbidity is considered "muddy" is unacceptable to be marketed as clear juices (Floribeth et al., 1981).

Enzymatic treatment leads to increase the clarity of juice. Juice clarity can be determined in terms of absorbance and transmittance at $660 \mathrm{~nm}$ using UV visible spectrophotometer.Increase in enzymatic concentration increase the rate of clarification by exposing part of the positively charged protein beneath thus reducing electrostatic repulsion between cloud particles which caused these particles to aggregate into larger particles and eventually settled out (Sin et al., 2006). Clarity showed the lowest absorbance values at highest enzyme concentration, where lower absorbance indicates a clearer juice is being produced. It was also observed that the absorbance values decreased with increasing incubation time at fixed temperature. In general, the time required to obtain a clear juice is inversely proportional to the concentration of enzyme used at constant temperature (Kilara, 1982). At the lowest level of temperature, the clarity of banana juice was found to increase rapidly at the beginning but with a slower rate towards the end, with an increase in enzyme concentration. The temperature increases the rate of enzymatic reactions, hence the rate of clarification, as long as the temperature is below 
denaturation temperature for the enzyme. A similar behaviour for the clarity was observed for the changes in incubation time in case of banana (Lee et al., 2006). The clarity of centrifuged litchi juice increased with an increase in enzyme concentration.

Among the different concentrations used for the optimization of pectinase, the litchi pulp added with $500 \mathrm{ppm}$ of pectinase resulted in maximum transmittance of $80 \%$ at $660 \mathrm{~nm}$. The clarity of

Table 1: Optimized conditions for clarification of variou

\begin{tabular}{|c|c|c|c|c|c|}
\hline Fruit/ Vegetable & $\begin{array}{l}\text { Incubation } \\
\text { time }^{\mathrm{a}}\end{array}$ & $\begin{array}{l}\text { Incubation } \\
\text { temperature }^{\mathrm{b}}\end{array}$ & $\begin{array}{c}\text { Enzyme } \\
\text { concentration }^{\mathrm{c}}\end{array}$ & Clarity $^{\mathrm{d}}$ & Referance \\
\hline $\begin{array}{c}\text { Banana (Musa sapientum } \mathrm{cv} \\
\text { Berangan) }\end{array}$ & 80 & 43.2 & $0.084 \%$ & $0.009 \mathrm{Abs}$ & Lee et al.,(2006) \\
\hline $\begin{array}{c}\text { Carambola (Carambola } \\
\text { Averrhoa L.) }\end{array}$ & 20 & 30 & $0.10 \%$ & $0.019 \mathrm{Abs}$ & $\begin{array}{l}\text { Abdullah et } \\
\text { al.,(2007) }\end{array}$ \\
\hline White Grape (Vitis vinifera) & 30 & $27-30$ & $0.048 \%$ & $0.031 \mathrm{Abs}$ & $\begin{array}{c}\text { Sreenath and } \\
\text { Santhanam, (1992) }\end{array}$ \\
\hline Sapodilla (Achras sapota) & 120 & 40 & $0.1 \%$ & $0.023 \mathrm{Abs}$ & Sin et al.,(2006) \\
\hline $\begin{array}{c}\text { Mosambi (Citrus sinensis (L.) } \\
\text { Osbeck) }\end{array}$ & 99.27 & 41.89 & $0.0004 \mathrm{w} / \mathrm{v} \%$ & $83.97 \% \mathrm{~T}$ & Rai et al.,(2003) \\
\hline Lichi (Litchi chinensis L) & 120 & 40 & $500 \mathrm{ppm}$ & $80 \% \mathrm{~T}$ & $\begin{array}{l}\text { Vijayanand et al., } \\
\text { (2010) }\end{array}$ \\
\hline
\end{tabular}

${ }^{\mathrm{a}}$ Incubation time in minutes, ${ }^{\mathrm{b}}$ Incubation temperature in ${ }^{0} \mathrm{C},{ }^{\mathrm{c}}$ Enzyme concentrations in ${ }^{\mathrm{a}} \mathrm{w} / \mathrm{v} \%$ : Weight per volume, ppm: parts per million, $\%$ : Percentage on pulp basis, ${ }^{\mathrm{d}}$ Clarity in Abs: Absorbance, T: Transmittance.

Table 2: Effect of Incubation time, Temperature and Enzymatic concentration on Turbidity at optimized condition using enzymatic treatments

\begin{tabular}{|c|c|c|c|c|c|c|}
\hline Fruit/ Vegetable & Enzymes $^{a}$ & $\begin{array}{c}\text { Incubation } \\
\text { time }^{\mathrm{b}}\end{array}$ & $\begin{array}{c}\text { Incubation } \\
\text { Temperature }^{\mathrm{c}}\end{array}$ & $\begin{array}{c}\text { Enzyme } \\
\text { Concentration }^{\mathrm{d}}\end{array}$ & Turbidity $^{\mathrm{e}}$ & Referances \\
\hline $\begin{array}{l}\text { Elderberry (Sambucus } \\
\text { nigra L) }\end{array}$ & Pectinase & 50 & 60 & $0.34 \mathrm{mg} / 100 \mathrm{gm}$ & $154 \mathrm{FNU}$ & $\begin{array}{l}\text { Landbo et } \\
\text { al., (2007) }\end{array}$ \\
\hline $\begin{array}{l}\text { Banana (Musa } \\
\text { sapientum cv Berangan) }\end{array}$ & Pectinase & 80 & 43.2 & $0.084 \%$ & $3.62 \mathrm{NTU}$ & $\begin{array}{l}\text { Lee } e t \\
\text { al.,(2006) }\end{array}$ \\
\hline $\begin{array}{l}\text { Sapodilla (Achras } \\
\text { sapota) }\end{array}$ & Pectinase & 120 & 40 & $0.1 \%$ & $\begin{array}{l}16.44 \\
\text { NTU }\end{array}$ & $\begin{array}{l}\text { Sin et } \\
\text { al.,(2006) }\end{array}$ \\
\hline $\begin{array}{l}\text { Carambola (Carambola } \\
\text { Averrhoa L.) }\end{array}$ & Pectinase & 20 & 30 & $0.10 \%$ & $\begin{array}{l}20.30 \\
\text { NTU }\end{array}$ & $\begin{array}{l}\text { Abdullah et } \\
\text { al., (2007) }\end{array}$ \\
\hline $\begin{array}{l}\text { Date (Phoenix } \\
\text { dactylifera L.) Variety } \\
\text { Deglet Nour }\end{array}$ & $\begin{array}{l}\text { Pectinase and } \\
\text { cellulase }\end{array}$ & 120 & 50 & $\begin{array}{l}\text { 50U pectinase / } \\
5 \mathrm{U} \text { cellulase }\end{array}$ & $\begin{array}{l}186.45 \\
\text { NTU }\end{array}$ & $\begin{array}{l}\text { Abbes et al., } \\
(2011)\end{array}$ \\
\hline Plum & $\mathrm{PME}$ and $\mathrm{PG}$ & 120 & 50 & $0.05 \mathrm{~g} / \mathrm{kg}(2: 1)$ & 590 NTU & $\begin{array}{l}\text { Mieszczako } \\
\text { wska-Frac } \\
(2012)\end{array}$ \\
\hline
\end{tabular}

${ }^{\text {a }}$ PME:Pectin Methyl Esterase ; PG: Polygalacturonase, ${ }^{\mathrm{b}}$ Incubation time in minutes, ${ }^{\mathrm{c}}$ Incubation temperature in ${ }^{0} \mathrm{C},{ }^{\mathrm{d}}$ Enzyme concentrations

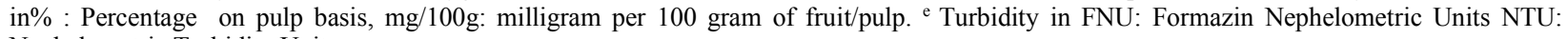
Nephelometric Turbidity Units. 
In case of elderberry it was observed very clearly from the turbidity data that ranged from 120 161 FNU with enzyme addition, and thus on average turbidity was $30 \%$ lower than those of samples produced without enzyme addition that had turbidity levels ranging between 191-212 FNU (Landbo et al., 2007). Since the turbidity in the juices may be due to pectin and other plant cell wall substances released during the enzymatic prepress maceration, it seems logic that elevated turbidities may transiently result during enzyme catalyzed cell wall degradation, which can partly explain the positive effect coefficient of the enzyme dosage on the turbidity. Turbidity in fruit juices can be a positive or a negative attribute depending on the expectation of the consumers (Hutchings, 1999). In the case of orange and tomato juices, the juices are usually cloudy and have colloidal suspensions. However, this cloud is desirable and acceptable by the consumers. Turbidity of juice at optimized condition for enzymatic treatment of various fruits and vegetable shown in Table 2. Increase in enzyme concentration and incubation time might decrease turbidity. Pectin was the main cause of turbidity (Grassin and Fauquembergue, 1996a). As the clarification process took place, the amount of pectin in the juices decreased, therefore reducing the turbidity of the juices (Alvarez et al., 1998).

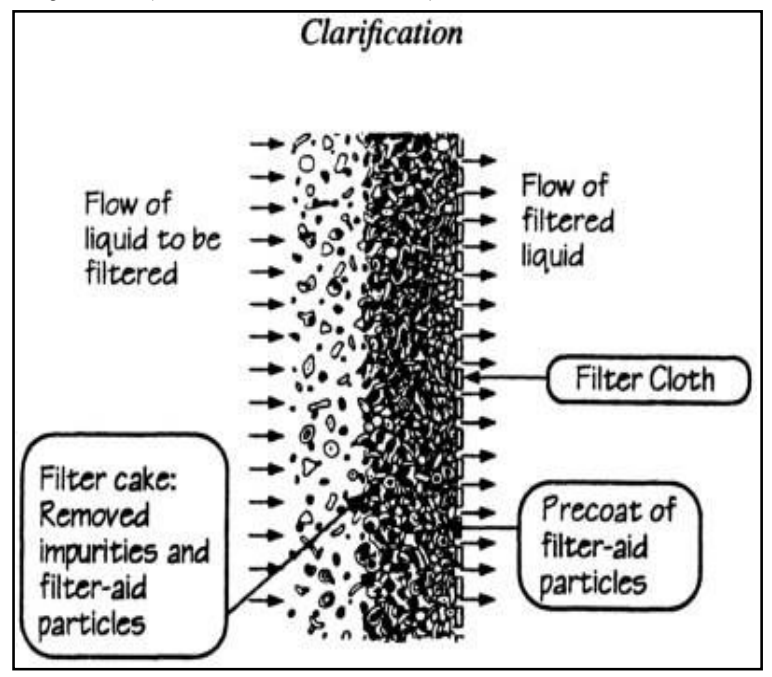

Fig.1: Diatomaceous earth (DE) filtration

The use of filter aids in filtration operations is one of the most traditional techniques to achieve a clarified juice. It is not as popular as in the past due to safety restrictions in handling the material and cost of waste disposal. It involves a three-step operation in element (paper, cloth, or screen), and then filtration is conducted using the continuous addition of filter aid to the juice.

\section{Non-enzymatic clarification of juices}

Nonenzymatic clarification involves breaking the emulsion by other means, the most common of which is heat (Smock and Neubert, 1950). Other techniques include addition of gelatin, casein, and tannic acid-protein combinations (Kilara and Van Buren, 1989). Additionally, the use of honey and combined honey-pectinase treatments have been found to be effective clarification agents (Kime, 1982). It is believed that the proteinaceous component of honey is responsible for a synergistic effect when honey and pectinase are used in combination (McLellan et al., 1985).A high-solids stream can be partially clarified using decanters and finishers. Both pieces of equipment operate on the same principle with a spinning central cone, drum, and set of paddles pushing the juice through a screen of some type. The unit is typically mounted horizontally, and throughput is relatively high.

A very common unit used for removal of juice-insoluble solids is the centrifuge. A centrifuge places the juice under high gravimetric force induced by centrifugal action. This is effective in producing a juice that is opaque but free of visible solids. Modern centrifuges are highly automated and run continuously with timed solids ejection. Centrifuges with a high force of gravity are capable of producing clear juice under optimized conditions. Operation of the centrifuge must be done in a way that minimizes the introduction of excessive oxygen in the product.

which a precoat of filter aid is built up on a filtration Membrane filtration in the fruit juice industry has grown from a novel approach into a reliable and economically attractive standard unit operation. Membrane processing has been used for concentrating, clarifying/fractionating and/or purifying fruit juices and for enhancing process efficiency and profitability. This technique has provided an excellent alternative for manufacturing high quality fruit juices under more hygienic conditions. Microfiltration (MF) and ultrafiltration (UF) are cross flow filtration processes, which retain particles in a wide range from $10,000 \mathrm{Da}$ to $500,000 \mathrm{Da}$. MF and UF have been widely used for clarification of fruit juices such as pear and apple. However, studies suggest that UF juices are more susceptible to post bottling haze (PBH) than traditionally clarified juices (Nagel and Schobinger, 
1985). Membrane filtration processes include reverse osmosis, nano filtration, ultra filtration, and microfiltration. Advantages of membrane filtration over traditional clarification methods include reduced processing time, increased juice yield, elimination of filter aid and filter presses, better product quality, and reduced enzyme usage (Cheryan, 1998).

In addition, in recent years there has been an increasing demand for natural, free-additive products, motivating the juice processing industry to develop and employ free-additive clarification techniques. Ultra filtration is the mostly widespread free additive clarification method due to many advantages, including higher juice yield, cost reduction and high quality products (Gokmen et al., 2001). Ultra filtration (UF) is a membrane filtration process that separates particles based on molecular weight (Milnes, 1984; Cheryan, 1986). The process uses a cross-flow method of operation, as opposed to depth filtration used in DE filtration. It can be utilized to clarify apple juice, as well as other fruit juices (Heatherbell et al., 1977). It has been used commercially for this purpose in several plants in Europe, the U.S., and South Africa (Cheryan, 1998; O'Sullivan et al.,(1988); Möslang, 1984). Baumann et al., (1986) reported that apple juice ultra filtered with membranes of pore sizes between $10 \mathrm{kDa}$ and $0.22 \mathrm{~mm}$ presented large variations only in color. Veleirinho et al., (2008) reported that apple juice clarification was achieved by adding $0.5 \mathrm{~g} / \mathrm{L}$ of gelatin and $2.5 \mathrm{~g} / \mathrm{L}$ of bentonite to the enzymatically treated juice, at $50^{\circ} \mathrm{C}$ for $2 \mathrm{~h}$. The precipitate was removed by centrifugation (4000 rpm, $10 \mathrm{~min}$ ) and the clear juice was stored at $4^{\circ} \mathrm{C}$. In order to produce the clear juice, $150 \mathrm{~mL}$ of enzymatically treated juice were ultrafiltered through a regenerated cellulose membrane (Millipore, cut off $100 \mathrm{kDa}$ ), under $\mathrm{N}_{2}$ pressure. The clarified juice was stored until analysis at $4^{\circ} \mathrm{C}$.

In a study of clarification process of pectincontaining juice using ultrafiltration it has been observe that a typical pectin rich juice, clarified by ultrafiltration (cold sterilization) can have adequate shelf life without any heat treatment or addition of preservatives (Rai and De, 2009). In Lemon juice clarification process by ultrafiltration the optimum treatment conditions were: enzyme concentration 600 $\mathrm{U} / \mathrm{L}$, time $45 \mathrm{~min}$ and temperature $30^{\circ} \mathrm{C}$. Their application led to a $77 \%$ and $47 \%$ reduction of viscosity and turbidity, respectively. The enzymatic treatment was followed by ultrafiltration (cutoff value $=15 \mathrm{kDa}$ ). Analysis of the clarified juice indicated that enzyme depectinization permitted a higher permeate flux and a higher juice quality. The lemon juice obtained was clear, stable and characterized by viscosity $=0.7 \mathrm{~m} \mathrm{~Pa} \mathrm{~s}$, turbidity $=0.17 \mathrm{NTU}$, clarity $(A 650 \mathrm{~nm})=0.063$ and color $(A 420 \mathrm{~nm})=0.232$.
Microbiological study showed that lemon juice was free from aerobes, molds, enterobacteriaceae and coliforms and was microbiologically stable during 3 months storage (Maktouf et al., 2014). Cassano et al., (2007) observed that, In a membrane-based process for the clarification of the cactus pear juice, the rejection of the UF membrane towards betaxanthins was lower than the rejection measured for betacyanins. Only a 4\% loss in the total antioxidant activity was found in the UF permeate with respect to the fresh juice. In osmotic distillation process the clarified juice with a TSS content of about $11^{\circ}$ Brix was concentrated up to 61 ${ }^{\circ}$ Brix. An initial evaporation flux of $1.16 \mathrm{~kg} / \mathrm{m}^{2} \mathrm{~h}$ was obtained using a calcium chloride dehydrate solution at $60 \mathrm{w} / \mathrm{w} \%$ as stripper.

\section{Conclusion}

Now a days a number of methods are used for clarification of juice i.e. enzymatic clarification, ultrafiltration, centrifugation, earth filtration and cross flow membrane filtration. Enzymatic treatment for juice extraction is most commonly used now a days. Enzymes are an integral component of modern fruit juice manufacturing and are highly suitable for optimizing processes. Advantages of membrane filtration over traditional clarification methods include reduced processing time, increased juice yield, elimination of filter aid and filter presses, better product quality, and reduced enzyme usage. We can conclude from the technical literature that use of the enzymes i.e. Cellulases, pectinases, combination of these enzymes and some non enzyme process can give better quality in terms of clarity of the fruit juice.

\section{References}

1. Abbes, F., Bouaziz, M., Blecker, C., Masmoudi, M., Attia, H., and Besbes, S. (2011). Date syrup: Effect of hydrolytic enzymes (pectinase/cellulase) on physicochemical characteristics, sensory and functional properties. Food Sci. Technol. 44: 1827-1834.

2. Abdullah, A.G.L., Sulaiman, N.M., Aroua, M.K., and Megat Mohd Noor, M.J. (2007). Response surface optimization of conditions for clarification of carambola fruit juice using a commercial enzyme. J. Food Engg. 81: 65-71.

3. Alvarez, S., Alvarez, R., Riera, F. A., and Coca, J. (1998). Influence of depectinization on apple juice ultrafiltration. Colloids and Surfaces A: Physicochemical and Engineering Aspects. 138: 377-382.

4. Bauman, J.W. (1981). Application of enzymes in fruit juice technology. Enzy. Food Proces. Birch. 129-147.

5. Baumann, G., Strobel, B., and Gierschner, K. (1986). Microfiltration and ultrafiltration of apple juice - comparison of inorganic/organic 
membranes and conventional deep-bed filters. Flüssiges Obst.53:251.

6. Bhat, M.K. (2000). Cellulases and related enzymes in biotechnology. Biotechnol. Advan. 18: 355-383.

7. Brown, M.R. and C.S. Ough. (1981). A comparison of activity and effects of two commercial pectic enzyme preparations on white grape musts and wines. Amer. J. Enol. Viticult. 32: 272-276.

8. Cassano, A., Conidi, C., Timpone, R., D’Avella, M., and Drioli E. (2007). A membrane-based process for the clarification and the concentration of the cactus pear juice. J. Food Engg. 80: 914921.

9. Cheryan, M. (1986). Ultrafiltration Handbook.Technomic Publishing, Lancaster, PA.

10. Cheryan, M. (1998). Ultrafiltration and Microfiltration Handbook. Technomic Publishing, Lancaster, PA.

11. Dorreich, K. (1996). Investigations on production of apple juice without the utilization of presses. In XII International congress of fruit juice report of congress (pp. 183-197). IFU, Interlaken. 20-24 May.

12. FAO STAT. 2010. Food and Agriculture Organization Statistical Production Yearbook.2010-2011, FAO, Rome, Italy.

13. Floribeth, V., Celsa, L., and Cooke, R. D. (1981). A study of the production of clarified banana juice using pectinolytic enzymes. Food Technol. 16: $115-125$.

14. Galante, Y.M., De Conti, A., and Monteverdi, R. (1998b). Application of Trichoderma enzymes in food and feed industries. Trichoderma \& Gliocladium-Enzymes, Biological Control and Commercial Applications. 2: 327-342.

15. Gokmen, V., Artik, N., Acar, J, Kahraman, N., and Poyrazoglu, E. (2001). Effects of various clarification treatments on patulin, phenolic compound and organic acid compositions of apple juice. Europ.Food Res.Technol. 213: 194-199.

16. Grassin, C., and Fauquembergue, P. (1996a). Fruit juices. In. Industrial enzymology, 2: 226.

17. Heatherbell, D.A., Short, J.L., and Strübi, P. (1977). Apple juice clarification by ultrafiltration. Confructa.22(5-6): 157.

18. Hutchings, J. B. (1999). Food colour and appearance. An Aspen Publication. 2: 19-21.

19. Indian Horticulture Database (2013). Indian Horticulture Board, Ministry of Agriculture, Government of India, India.

20. Joshi, V.K., Chauhan, S.K., amd Lal, B.B. (1991). Extraction of juice from peaches, plumes and apricot by pectinolytic treatment. J. Food Sci. Technol.. 28(1): 64-65.
21. Kashyap, D. R., Vohra, P. K., Chopra, S., and Tewari, R. (2001). Applications of pectinases in the commercial sector: a review. Bioresource Technol. 77: 215-227.

22. Kaur, G., Kumar, S., and Satyanarayana, T. (2004). Production, characterization and application of a thermostable polygalacturonase of a thermophilic moul Sporotrichum Termophile. Bioresource Technol., 94, 239-243.

23. Kilara, A. (1982). Enzymes and their uses in the processed apple industry: A review. Process Biochem. 17: 35-41.

24. Kilara, A. and Van Buren, J. (1989). Clarification of apple juice. In:Processed Apple Products, D.L. Downing (Ed.), Van Nostrand Reinhold, New York.

25. Kime, R.W. (1982). Clarification of fruit juice with honey. United States Patent 4,327,115.

26. Landbo, A.K., Kaack, K., and Meyer, A.S. (2007). Statistically designed two step response surface optimization of enzymatic prepress treatment to increase juice yield and lower turbidity of elderberry juice. Innov. Food Sci. Emerg. Technologie. 8: 135-142.

27. Lee, W.C., Yusof, S., Hamid, N.S.A., and Baharin, B.S. (2006). Optimizing conditions for enzymatic clarification of banana juice using response surface methodology (RSM). J. Food Engg. 73: 55-63.

28. McLellan, M.R., Kime, R.W., and Lind, L.R. (1985). Apple juice clarification with the use of honey and pectinase. J. Food Sci.50: 206-208.

29. Mieszczakowska-Frac, M., Markowski, J., Zbrzezniak, M., and Plocharski, W. (2012). Impact of enzyme on quality of blackcurrant and plum juices. Food Sci.Technol. 49: 251-256.

30. Milnes, B.A. (1984). The application of ultrafiltration to apple juice processing. New York State Agricultural Experimental Station Special Report,No. 54, D.L. Downing (Ed.), Geneva, NY.

31. Möslang, H. (1984). Ultrafiltration in the fruit juice industry. Confructa.28(3): 219.

32. Nagel, C.W., Schobinger, U. (1985). Investigation of the Origin of Turbidity in Ultrafiltered Apple and Pear Juice Concentrate. Confructa Studien.26: 16.

33. O'Sullivan, T., Simons, and Epstein, A. (1988). For winemakers- a simplified introduction to ultrafiltration.Vineyard Winery Mgt.3: 65.

34. Rai, P., and De, S. (2009). Clarification of pectincontaining juice using ultrafiltration. Current Sci.. 96(10): 1361-71.

35. Rai, P., Majumdar, G.C., DasGupta, S., and De, S. (2003). Optimizing pectinase usage in pretreatment of mosambi juice for clarification by 
response surface methodology.J. Food Engg.64: 397-403.

36. Maktouf, S., Neifar, M., Drira,S.J., Baklouti, S., Fendri,M. and Châabouni, S. E. (2014). Lemon juice clarification using fungal pectinolytic enzymes coupled to membrane ultrafiltration. Food Bioproduct.Proces. 92: 14-19.

37. Sin, H.N., Yusof, S., Sheikh Abdul Hamid, N., and Abd. Rahman, R. (2006). Optimization of enzymatic clarification of sapodilla juice using response surface methodology. J. Food Engg.73: 313-319.

38. Smock, R.M. and Neubert, A.M. (1950). Apples and Apple Products. Interscience Publishers, New York.

39. Sreenath, H. K. and Santhanam, K. (1992). The use of commercial enzymes in white grape juice clarification. J. Fermen. Bioengg. 73(3): 241-243.

40. Sulaiman, M. Z., Sulaiman, N. M., and Liew, S. Y. (1998). Limiting permeate flux in the clarification of untreated starfruit juice by membrane ultrafiltration. Chem. Engg. J. 69(2): 145-148.
41. Tribess, T. B., and Tadini, C. C. (2006). Inactivation kinetics of pectin methyesterase in orange juice as a function of $\mathrm{pH}$ and temperaturetime process conditions. J. Sci. Food Agric.86: 1328-1335.

42. Uhlig, H. (1998). Industrial enzymes and their applications. New York: John Wiley \& Sons, Inc. 435.

43. Vaillant, F., Millan, A., Dornier, M., Decloux, M., and Reynes, M. (2001). Strategy for economical optimisation of the clarification of pulpy fruit juices using crossflow microfiltration. J. Food Engg. 48: 83-90.

44. Veleirinho, B., Rei, MF, Silva, JAL-DA (2008). Solvent and concentration effects on the properties of electrospun poly (ethylene terephthalate) nanofiber mats. J.Polymer Sci. Part B: Polymer Physics. 46: 460-71.

45. Vijayanand, P., Kulkarni, S. G., and Prathibha G. V. (2010). Effect of pectinase treatment and concentration of litchi juice on quality characteristics of litchi juice. J. Food Sci.Technol. 47(2): 235-239. 